\title{
Pedagogika przygody - uczenie się bycia razem, uczenie się wspólnego działania
}

\begin{abstract}
Streszczenie
Zgodnie z wytycznymi UE współczesne kształcenie powinno koncentrować się na umiejętności uczenia się. Przewiduje się, że większość profesji, które znane są dziś - za kilkanaście lat zniknie, a w ich miejsce pojawią się nowe. Rynek pracy będzie wymagał umiejętności współpracy w zespole, kreatywnego myślenia, rozwiązywania problemów. Za tymi wszystkimi zmianami i wymaganiami nie nadąża formalny system edukacji.

Od kilkunastu lat w Polsce poszerza się ruch działań związanych z pedagogiką przygody: powstają organizacje działające w tym nurcie, nawiązują ze sobą współpracę, wchodzą w struktury międzynarodowe, rozbudowuje się sieć leśnych przedszkoli.

Samo pojęcie „pedagogiki przygody” jest znane na razie wąskiemu gronu edukatorów i animatorów. Założenia kojarzone są z harcerstwem choć nie powinny być z nim utożsamiane.

Pedagogika przygody to działania z obszaru przede wszystkim edukacji pozaformalnej, ale wzorem Słowenii czy Wielkiej Brytanii próbuje również w Polsce wkraczać do szkół. Z powodzeniem sprawdza się w działaniach socjoterapeutycznych, coraz częściej włączana jest w działania przez organizacje harcerskie i firmy.
\end{abstract}

1 Ewa Palamer-Kabacińska, Wydział Pedagogiczny, Uniwersytet Warszawski, Polska, e-mail: e.palamer@uw.edu.pl, ORCID ID: https://orcid.org/0000-0002-6251-0941. 
Czym zatem jest pedagogika przygody? Czy i dlaczego warto w nią inwestować? Jakie są jej założenia? Jakich kompetencji i umiejętności uczy? W niniejszym artykule zostanie podjęta próba odpowiedzi na te pytania w nawiązaniu do badań własnych przeprowadzonych w ramach programów przygodowych realizowanych w latach 2015-2018.

\title{
Słowa kluczowe:
}

pedagogika przygody, program przygodowy, metoda przygodowa, kompetencje społeczne, współpraca

\begin{abstract}
According to EU guidelines, modern education should focus on learning skills. It is anticipated that most of the professions that are known today will disappear in a dozen or so years and new ones will replace them. The labor market will require teamwork skills, creative thinking and problem solving. The formal education system cannot keep up with all these changes and requirements.

For several years the movement of activities related to adventure education has been expanding in Poland: organizations operating in this trend are established, cooperate with each other, enter into international structures, and the network of forest kindergartens is expanding.

The very concept of "adventure education" is known to a small group of educators and animators for now. Assumptions are associated with scouting - although they should not be equated with it.

Adventure education is primarily in the field of non-formal education, but following the example of Slovenia or Great Britain, it is also trying to enter schools in Poland. It is successfully used in sociotherapeutic activities, and is increasingly involved in activities by scout organizations and commercial companies.

So what is adventure education? Is it worth investing and why? What are its assumptions? What competences and skills does it teach? This article will attempt to answer these questions in relation to own research carried out as part of the adventure programs implemented in the years 2015-2018.
\end{abstract}

\section{Keywords:}

outdoor/adventure education, adventure program, outdoor/adventure method, social competence, cooperation 


\section{KLUCZOWE KOMPETENCJE}

Według dokumentu przyjętego przez Unię Europejską kompetencje to kompilacja wiedzy, umiejętności i postaw, przy czym wiedza to „fakty i liczby, pojęcia, idee i teorie, które są już ugruntowane i pomagają zrozumieć określoną dziedzinę lub zagadnienie”; umiejętności definiowane są jako „zdolność i możliwość realizacji procesów i korzystania z istniejącej wiedzy do osiągania wyników”; natomiast postawy określane są jako „gotowość i skłonność do działania lub reagowania na idee, osoby lub sytuacje” (Zalecenie Rady, 2018: C 189/7).

Kompetencje kluczowe pełnią określone funkcje w życiu człowieka - dzięki nim możliwy jest rozwój osobisty, możliwość podjęcia zatrudnienia, funkcjonowanie w grupach społecznych, podejmowanie zdrowego stylu życia (zarówno pod względem fizycznym, jak i psychicznym - emocjonalnym), a także aktywne uczestnictwo w społeczeństwie obywatelskim. Kompetencje te nabywane i rozwijane są w toku całego życia - wpisując się w założenia koncepcji całożyciowego uczenia się, poprzez uczenie się formalne, pozaformalne i nieformalne realizowane w różnych obszarach życia: rodzinnego, zawodowego, rówieśniczego.

Uczenie się formalne związane jest z państwowymi instytucjami, zazwyczaj dotyczy szkół, do których uczęszczanie zobligowane jest obowiązkiem szkolnym. Pozaformalne uczenie natomiast, które również związane jest z instytucjami, cechuje się dobrowolnością uczestnictwa, programem tworzonym oddolnie - i przede wszystkim - odpowiedzialnością za uczenie się leżącą po stronie uczącego się. Trzeci typ uczenia się - nieformalne, odmiennie od wcześniej wymienionych, nie ma charakteru celowego, jest incydentalne, niemożliwe do zaplanowania, a jego efekty trudne są do przewidzenia (Uczyć się inaczej..., 2014).

Kształcenie do kompetencji potrzebnych do funkcjonowania we współczesnym świecie podkreśla istotę uczenia się pozaformalnego i nieformalnego, które poparte jest doświadczeniem zdobytym w działaniach w obszarze kultury, przez pracę z młodzieżą, wolontariat oraz sport. W ramach tych dwóch typów uczenia się rozwijane być mogą umiejętności interpersonalne, komunikacyjne oraz poznawcze, które przejawiają się w zdolności krytycznego i analitycznego myślenia, kreatywności, umiejętności rozwiązywania problemów oraz odporności na sytuacje stresowe. Rozwinięcie wymienionych zdolności pozwala na przejmowanie odpowiedzialności za swoje dorosłe życie, przyjmowanie aktywnych postaw obywatelskich oraz zawodowych (Zalecenie Rady, 2018).

Z drugiej strony wyniki badań wskazują na to, że poziom umiejętności podstawowych ludności krajów UE jest na niezadowalającym poziomie. Z analiz wynika, że około $20 \%$ badanych uczniów nie osiąga wystarczającego poziomu umiejętności 
czytania ze zrozumieniem, myślenia matematycznego oraz rozumienia zjawisk przyrodniczych. W niektórych krajach problem dotyczy również dorosłych - 1/3 z nich wykazuje umiejętność tworzenia i rozumienia informacji oraz rozumowania matematycznego na najniższym poziomie. Z kolei blisko połowa badanych w całej Unii ma niskie kompetencje cyfrowe, a prawie 1/5 - nie posiada wcale takich kompetencji. W związku z powyższym powinno się stawiać na edukację o najwyższej jakości, w tym również tę pozaformalną - gdyż to powoduje rozwój owych umiejętności podstawowych.

Zalecenia Rady Unii Europejskiej z 22 maja 2018 roku modyfikują wcześniejsze ustalenia z 2006 roku w sprawie kompetencji kluczowych w procesie uczenia się przez całe życie, co ma związek z „z rosnącą liczbą miejsc pracy poddanych automatyzacji, coraz istotniejszą rolą technologii we wszystkich dziedzinach pracy i życia oraz zwiększającym się znaczeniem kompetencji społecznych, obywatelskich i w zakresie przedsiębiorczości, które pozwalają zapewnić odporność i zdolność dostosowania się do zmian” (Zalecenie Rady, 2018: C 189/1). Wiąże się to z koniecznością wprowadzenia nowych, innowacyjnych metod uczenia się, a także opracowania skutecznych i rzetelnych narzędzi ich walidacji.

Nowy zestaw to osiem kompetencji: rozumienie i tworzenie informacji, wielojęzyczność, matematyczne oraz w zakresie nauk przyrodniczych, technologii i inżynierii, kompetencje cyfrowe, osobiste, społeczne i w zakresie umiejętności uczenia się, obywatelskie, w zakresie przedsiębiorczości, świadomości i ekspresji kulturalnej. Warto tu podkreślić, że wcześniejsze zalecenia również formułowały osiem kompetencji, z tą różnicą jednak, że wskazywano na jedną podstawową określaną jako metakompetencję - która była podstawa do osiągnięcia wszystkich pozostałych - umiejętność uczenia się. Obecnie umiejętność ta znalazła się wraz z kompetencjami osobistymi, społecznymi. Uważa się, że wszystkie określone kompetencje są równie ważne, co więcej - ich zakresy często się pokrywają i wzajemnie się wspierają. Wspólnym elementem, występującym we wszystkich kompetencjach, są takie umiejętności, jak: „krytyczne myślenie, rozwiązywanie problemów, praca zespołowa, umiejętności komunikacyjne i negocjacyjne, umiejętności analityczne, kreatywność i umiejętności międzykulturowe” (Zalecenie Rady, 2018: C189/7).

Z punktu widzenia podjętego tematu najważniejsze są wspomniane kompetencje osobiste, społeczne i w zakresie umiejętności uczenia się. Kryją one w sobie umiejętność:

- autorefleksji,

- zarządzania czasem i informacjami,

- planowania i podejmowania uczenia się, koncentracji na zadaniu, co powiązane jest z określaniem swoich możliwości i budowaniem poczucia pewności siebie, 
- podejmowania współpracy, a tym samym - zdolność do empatycznego współodczuwania, konstruktywnego porozumiewania się w różnych środowiskach, negocjowania i podejmowani kompromisów, postawy tolerancyjne,

- radzenia sobie z sytuacjami problemowymi, konfliktowymi, co wiąże się z odpornością na sytuacje stresowe,

- wspierania prozdrowotnego stylu życia (w aspekcie psychicznym i fizycznym).

U podstaw tych kompetencji leżą:

- pozytywne nastawienie do samego siebie - w kontekście osobistym, społecznym i fizycznym,

- umiejętność współpracy, postawa asertywna oraz prawość,

- poszanowanie różnorodności innych osób wraz z gotowością pokonywania uprzedzeń,

- umiejętność osiągania kompromisu,

- umiejętność wyznaczania sobie celów,

- zdolność do automotywacji,

- umiejętność rozwiązywania problemów, radzenia sobie z przeszkodami i zmianami,

- zdolność do autorefleksji nad wcześniejszymi doświadczeniami i umiejętność wykorzystania ich w przyszłych działaniach.

Warto także podkreślić, że mimo iż główny nacisk kładziony jest przede wszystkim na kształcenie w naukach ścisłych: przyrodniczych, matematycznych i inżynieryjnych (tzw. STEM) - to jednak postuluje się łączenie owego kształcenia z innymi dziedzinami, co może się przyczynić do skuteczniejszej edukacji w tym obszarze. Nauki matematyczno-przyrodnicze dobrze jest łączyć „ze sztuką i innymi dziedzinami, z wykorzystaniem pedagogiki opartej na samodzielnych poszukiwaniach i przy zaangażowaniu szerokiego spektrum podmiotów społecznych i branż” (Zalecenie Rady, 2018: C 189/3).

\section{WYMAGANIA RYNKU PRACY}

Dynamiczne zmiany związane z rozwojem technologii i cyfryzacji powodują również zmiany na rynku pracy. Prognozuje się, że wzrastająca cyfryzacja będzie wymagała od obecnych i przyszłych pracowników nowego podejścia do pracy zawodowej. Podstawowym wymaganiem utrzymania się na rynku pracy są kompetencje cyfrowe. Ale nie tylko - dynamika zmian, brak pewności zatrudnienia wymagają również nowego nastawienia do pracy zarobkowej. 
Przewiduje się, że w ciągu najbliższych lat z powodu automatyzacji niektóre zawody znikną z listy dotychczas wykonywanych, a z kolei powstaną nowe w sektorach pracy oferujące nieznane dotąd usługi. Rozwój technologii spowoduje również inne formy zatrudnienia oraz interakcji między pracodawcą a pracownikiem. Brak stabilizacji rynku wymagać będzie wysokiego poziomu kompetencji miękkich, w tym również społecznych. Pracownicy będą zmuszeni do zmiany nastawienia do pracy - ceniona będzie elastyczność, umiejętność współpracy z różnymi zespołami, rozwiązywania problemów, stawania przed nowymi wyzwaniami. Preferowane będzie zatrudnianie w formie projektowej - co z jednej strony daje wolność wyboru i decyzji w kwestii rodzaju podejmowanej pracy, ale z drugiej - większą niepewność co do swojej przyszłości. Tego typu zatrudnienie wymaga odporności na stres, a także umiejętności planowania różnych ścieżek swojej przyszłości. Na rynku pracy cenione będą osoby, które będą posiadały kompetencje e-liderów, czyli „czyli osób, które będą potrafiły łączyć kompetencje cyfrowe, biznesowe i zarządcze” (Raport, 2017, s. 9-10).

Przewidywania co do rynku pracy pokazują, że ulegnie on dużym przekształceniom - około 5\% zawodów zniknie, a około połowy obecnych zawodów ulegnie przynajmniej częściowej automatyzacji. Te, które prawdopodobnie nie zostaną poddane temu procesowi, to: terapeuta i psycholog, pielęgniarka, duchowny, lekarz, wykładowca, opiekunka do dzieci. Najbardziej zagrożone automatyzacją są: murarz/tynkarz, urzędnik lub pracownik administracji, robotnik rolny, sprzedawca/ asystent sprzedaży, recepcjonistka, księgowy, pracownik dz. personalnego i płacowego, bibliotekarz, agent ubezpieczeniowy, urzędnik w banku lub na poczcie, sprzedawca przez telefon.

Profesje, które nie są zagrożone ryzykiem automatyzacji, pozostaną „ponieważ ich wykonywanie opiera się na kompetencjach i umiejętnościach, które trudno ująć w algorytmy. Należą do nich przede wszystkim oryginalność/kreatywność i inteligencja społeczna, jak również umiejętność działania nierutynowego. [...] najmniej zagrożone automatyzacją są zawody, w których trzeba wykorzystywać kreatywność, pomysłowość i umiejętność tworzenia nowych idei oraz wchodzić w relacje z innymi ludźmi” (Raport, 2017, s. 18). Do tzw. zawodów kreatywnych zalicza się artystów, designerów, przedstawicieli wolnych zawodów - ale także pracowników uniwersytetów. „Osoby pracujące w tych zawodach łączy to, że zajmują się twórczym rozwiązywaniem konkretnych problemów w oparciu o swą bogatą wiedzę, umiejętności i intuicję” (Raport, 2017, s. 22).

Powyższe dane i analizy pozwalają sformułować zalecenia, które w przyszłości pomogą się odnaleźć na zmieniającym się rynku pracy. Przede wszystkim istotne jest - wielokrotnie wcześniej podkreślane - rozwijanie kompetencji cyfrowych 
oraz zdolności matematycznych. Przestaje mieć znaczenie duża wiedza pamięciowa na rzecz „oceny wiarygodności źródeł wiedzy, interpretowania faktów, zwłaszcza w sytuacji sprzecznych doniesień, logicznego myślenia, koncentracji w sytuacji wielu rozpraszających uwagę czynników i przede wszystkim umiejętność współpracy z maszynami, systemami komputerowymi i sztuczną inteligencją” (Raport, 2017, s. 30). Wiąże się to z komplementarną współpracą człowieka z technologią. Jednakże wszystko to nie może się obyć bez rozwijania inteligencji społecznej, która opiera się między innymi na umiejętności zarządzania zespołem oraz podejmowania współpracy, a także elastycznego reagowania na zmiany. „W przyszłości na rynku pracy utrzymają się zwłaszcza te zawody, które opierają się na pracy interakcyjnej, czyli takiej, w której wchodzi się w kontakt z innymi ludźmi, empatycznie reaguje na ich potrzeby i dostarcza się im troskliwej uwagi” (Raport, 2017, s. 32).

Jak z powyższego widać - zarówno zalecania formułowane przez UE, jak i badania dotyczące rynku pracy w przyszłości w wielu aspektach się pokrywają. Jednym z celów kształcenia jest szukanie takich metod edukacyjnych, które wspierałyby rozwijanie kompetencji miękkich, w tym również społecznych, które mogą dać gwarancje do odnalezienia się w stale zmieniającej się rzeczywistości.

\section{PEDAGOGIKA PRZYGODY}

Nurt łączący w sobie założenia outdoor education, adventure education, niemieckiej i czeskiej pedagogiki przeżyć, w Polsce określany jest mianem pedagogiki przygody (Leśny, 2014, s. 45). Na rodzimym gruncie jest stosunkowo młodą, dopiero kształtującą się subdyscypliną. Nawiązuje do działań wywodzących się z Outward Bound - największej międzynarodowej organizacji o kilkudziesięcioletniej tradycji działań przygodowych (Outward Bound, b.d.).

Celem pedagogiki przygody są całościowy rozwój osobowości przez stawianie wyzwań w sferze psychicznej, fizycznej lub/i społecznej przy wykorzystaniu przygody jako środka oraz działania w grupie i przez grupę w kontakcie z przyrodą. Inaczej mówiąc: celem jest kształcenie umiejętności miękkich przez zastosowanie programu przygodowego - zaplanowanej sekwencji celowych działań.

Uczestnik działań w wyniku zetknięcia się z zaplanowanym przez prowadzącego wyzwaniem musi zmierzyć się ze swoimi ograniczeniami, ale także odkrywa swoje nowe możliwości. Działanie zaplanowane jest w grupie - dzięki czemu uczestnik uczy się nowych ról społecznych, rozumie swoją pozycję w zespole, przełamuje swoje ograniczenia. Jest stawiany w sytuacjach trudnych, ale rów- 
nocześnie ma świadomość, że jest to sytuacja wykreowana - czyli bezpieczna (co można trochę porównać do odgrywania roli w teatrze) (Palamer-Kabacińska, 2012).

Działania powinny odbywać się w plenerze, najlepiej - na łonie natury, która jest źródłem dodatkowych bodźców. Wyjście z sytuacji szkolnej czy zawodowej uwalnia ludzi od konieczności odgrywania narzuconych ról (pracownika, ucznia), powoduje, że wszyscy - niezalenie od funkcji - stają się równi wobec zadania.

Metoda pedagogiki przygody (określana tu jako metoda przygodowa) opiera się na założeniu, że muszą być zastosowane pewne określone zasady, aby osiągnąć zaplanowany efekt. Pierwszym elementem jest postawienie przed grupą wyzwania o charakterze fizycznym, psychicznym lub/i społecznym. Przy czym, opierając się na modelu KNP (Leśny, 2014), należy uwzględnić indywidualne predyspozycje, możliwości i ograniczenia poszczególnych uczestników, tak aby stworzyć optymalne warunki do rozwoju. W nawiązaniu do owych indywidualnych predyspozycji, a co za tym idzie braku możliwości przewidzenia przez prowadzącego wszystkich reakcji uczestników (a także posiadania wiedzy o ich wszelkich doświadczeniach, słabościach, możliwościach) - stosuje się zasadę dobrowolności. Zasada ta (określana „zasadą STOP”) przewiduje możliwość rezygnacji z działania przez każdego z uczestników na każdym etapie wykonywania zadania. Użycie jej jest możliwe w sytuacji, kiedy dana sobą czuje, iż zadanie, które przed nią stoi, mieści się w jej sferze paniki, co kompletnie blokuje możliwości poznawcze i rozwojowe. Warto na marginesie zaznaczyć, że użycie tej zasady w trakcie zadania stawia grupę przed kolejnym wyzwaniem, ponieważ działania uznaje się za pozytywnie zakończone tylko wówczas, kiedy wykona je cały zespół. Grupa musi wykazać się empatią w stosunku do osoby, która powiedziała STOP, a także często pogodzić się z porażką - nieukończeniem zadania (co wcale nie jest takie złe z punktu widzenia założeń pedagogiki przygody).

Kolejnym kluczowym elementem jest planowanie działań w grupie i - „poprzez grupę”. Oznacza to, że grupa sama w sobie staje się źródłem nowych doświadczeń dla siebie samej. Zespół podlega procesom grupowym - tworzenia się hierarchii, struktury komunikacji, przyjmowania ról społecznych, podejmowania strategii rozwiązywania problemów - co stwarza warunki do uczenia się społecznego.

Planowane działania powinny być nastawione na współpracę, z wyłączeniem elementów rywalizacji czy współzawodnictwa.

Podstawą pedagogiki przygody - mieszczącej się w nurcie experiential education - jest postulat learning by doing, czyli uczenia się przez działanie, którego zastosowanie uzasadnia Cykl Kolba (Leśny, 2014). Człowiek najwięcej uczy się poprzez, w pierwszej kolejności, osobiste doświadczenie, a następnie przez 
namysł nad swoim działaniem, skutkujący wprowadzaniem zmian - i ponownym zastosowaniem ich w praktyce. Wiąże się to z kolejnym postulatem metody przygodowej - akceptacją niepowodzenia. W pedagogice przygody błąd uważa się za wychowawczy, kształcący, dający możliwość refleksyjnego spojrzenia na podejmowane decyzje i świadomego wprowadzania zmian w swoje postępowanie.

Zaplanowane wyzwanie opiera się na wykorzystaniu określonego środka przygodowego - aktywności, najlepiej plenerowej, która jest podstawą działania dla grupy, ale też „pretekstem” do rozwijania osobowości. Trzeba tu pamiętać, że owa zaplanowana przygoda (np. spływ kajakowy) jest tylko środkiem do osiągnięcia celu, nie jest celem samym w sobie. Koncentracja na procesie, a nie celu umożliwia wykorzystanie od strony wychowawczej zachodzących procesów grupowych. Środkiem przygodowym w takim projekcie może być każda aktywność - najbardziej typowe to wykorzystanie gier z pedagogiki przeżyć czy pedagogiki przygody, wędrówki, biwakowanie - ale środkiem przygodowym może być nauka matematyki, lektury szkolne czy język angielski.

Możliwość działania w plenerze, w przyrodzie dostarcza dodatkowych bodźców, a także sprawia, że staje się wobec wyzwań ze samym sobą - przetrwania mimo zimna, chłodu, ciemności. Nie oznacza to jednak, że pedagogikę przygody można jedynie realizować w dzikiej głuszy - jednak uwzględnienie tego elementu jest istotne dla intensywności odczuwania doświadczeń.

Planując działania, warto szukać warunków, które sprawią, że uczestnicy odczują „magię miejsca i momentu” (tzw. 3M), a także zaplanować przygodę, aby w kulminacyjnym momencie uczestnicy poczuli flow.

Działania w pedagogice przygody nie mogą obejść się bez refleksji na końcu zadania (nawiązując ponownie do wspomnianego wcześniej Cyklu Kolba), która odbywa się na trzech poziomach: oceny przez uczestników poziomu zrealizowania celu, analizy podejmowanych działań w grupie oraz osobistych doświadczeń i refleksji (Ryszka, 2016).

W wyniku realizacji zaplanowanych działań przygodowych u uczestników dokonuje się transfer wiedzy (z sytuacji wykreowanego doświadczenia, poprzez refleksję - do codziennych czynności); poszerza się strefa komfortu; wzrastają umiejętności: współpracy, rozwiązywania problemów, radzenia sobie w sytuacjach trudnych, rozwija kreatywność.

Założenia metody przygodowej realizowane są przez program przygodowy. Jest to zaplanowana sekwencja działań, w której bardzo ważnym elementem i równocześnie punktem wyjścia jest analiza potrzeb grupy. Na tej bazie konstruowany jest program działań, który kończy się refleksją. Programy przygodowe mogą mieć 
różny charakter - mogą być stacjonarne lub wyjazdowe, trwać kilka godzin lub kilka, a nawet kilkanaście dni (Ryszka, 2016).

Bardzo ważna w działaniach przygodowych jest rola prowadzącego - jest on obserwatorem z boku, pozwala grupie samodzielnie rozwiązywać zadania, przyzwala na konflikty, nie ingeruje, nie pomaga i nie przeszkadza - obserwuje. Rolą prowadzącego jest zwracanie uwagi na strategie, które podejmuje grupa przy rozwiązaniu zadania, sposób komunikacji, przyjmowane role grupowe, współpracę i atmosferę w grupie.

Często porównuje się go do facylitatora - ale warto pamiętać, że sposób prowadzenia grupy zależy też od rodzaju i etapu zadania oraz poziomu rozwoju grupy. Na poziomie integracji prowadzący powinien skupić się na zadaniach mających na celu zgranie grupy, a on sam powinien przyjąć funkcje liderskie, które pomogą grupie wejść w cały program przygodowy i zrozumieć jego zasady. Na etapie niezadowolenia prowadzący skupia się na pomocy zespołowi w samodzielnym rozwiązywaniu konfliktów, najczęściej poprzez stawianie pytań. Dba również o komunikację w zespole, pilnując zasad. Kiedy grupa jest na etapie nabywania pewności - prowadzący stopniowo coraz bardziej się wycofuje, aby wreszcie w momencie nabycia przez grupę pełnej sprawności działania - oddać jej całkowicie kontrolę, stając na pozycji obserwatora. Prowadzący ponownie wkracza do działania na koniec programu przygodowego, w trakcie podejmowania refleksji nad działaniem, starając się pomóc uporządkować nabyte doświadczenie i dzięki temu ułatwić transfer nowych umiejętności (Ryszka, 2016).

Analizując profil wspomnianego wcześniej e-lidera, można znaleźć wiele umiejętności, które pedagogika przygody pozwala rozwijać - co ciekawe - wcale nie przy pomocy cyfrowego świata. E-lider powinien cechować się umiejętnością przewidywania zapotrzebowania na informacje, rozumieć potrzeby konsumentów, być zorientowanym na szukanie rozwiązań, być kreatywnym, potrafić się uczyć, być dobrym w komunikacji, umieć zarządzać zespołem, umieć funkcjonować w międzynarodowym środowisku (Raport, 2017). Te umiejętności można kształcić za pomocą działań związanych z pedagogiką przygody.

Pedagogika przygody może również wspierać niektóre z wymagań nowego rynku pracy - takie jak rozwijanie inteligencji społecznej - w tym umiejętność współpracy, komunikacji oraz empatii; a także rozwiązywania problemów, organizowania pracy w zespole, świadomości swoich możliwości i ograniczeń - które są podstawą do szukania dalszych ścieżek kariery.

Można pokusić się o stwierdzenie, że pedagogika przygody najlepiej wpisuje się w realizację postulowanych przez UE kompetencji osobistych, społecznych i uczenia się. 


\section{PROGRAMY PRZYGODOWE}

W założeniach pedagogika przygody uczy współpracy - jednej z umiejętności wymaganych na nowym rynku pracy. Czy tak faktycznie jest?

Poniższe wnioski opierają się na wynikach analiz przeprowadzonych na podstawie autorskich programów przygodowych. W swojej praktyce nawiązuję do pedagogiki przeżyć, ze szczególnym uwzględnieniem założeń Prazdninvej Skoly Lipnice w Czechach, która kładzie duży nacisk z jednej strony na analizę potrzeb grupy, a z drugiej na znaczenie refleksji po zakończeniu programu przygodowego, a także jako jedna z pierwszych - zastosowała sztukę jako środek przygodowy (Prázdninová škola Lipnice, b.d.).

W latach 2015-2019 zostało przeze mnie zorganizowanych łącznie dwanaście programów przygodowych skierowanych do różnych grup odbiorców i o różnym charakterze pod względem sposobu organizacji. Programy te można pogrupować ze względu na: grupy odbiorców - dzieci i młodzież oraz młodzi dorośli; środowiska tancerze, członkowie organizacji harcerskich oraz studenci; sposób organizacji: krótkie - jednorazowe; cykliczne - rozłożone w czasie; długie - wyjazdowe, a także zastosowany środek przygodowy: taniec oraz gry przygodowe. Przy czym podział ze względu na środowisko nie jest jednoznaczny - ponieważ zarówno w grupach tanecznych, jak i studenckich znajdowali się harcerze/harcerki lub instruktorzy harcerscy.

Tabela 1. Zestawienie programów przygodowych zorganizowanych w latach 2015-2019 (opracowanie własne)

\begin{tabular}{lllll}
\hline \multicolumn{1}{c}{ Środek przygodowy } & $\begin{array}{l}\text { Środek przygodowy: } \\
\text { taniec }\end{array}$ & $\begin{array}{l}\text { Środek przygodowy: } \\
\text { gry }\end{array}$ & \\
\cline { 2 - 5 } & tancerze & studenci & & harcerze \\
\hline Długi wyjazdowy & Obóz 2015 & & & \\
& Obóz 2016 & & & \\
& Obóz 2017 & & & \\
& Obóz 2018 & & & \\
\hline Długi cykliczny & & PPT & PP 2017 & Kurs funkcyjnych 2019 \\
& & $2014 / 15$ & PP 2018 & \\
& & PPT & PP N & \\
& & $2015 / 16$ & 2018 & \\
\hline Krótki jednorazowy & & & & $\begin{array}{l}\text { Harcerski bieg } \\
\text { przygodowy 2017 } \\
\end{array}$ \\
& & & & $\begin{array}{l}\text { Zuchowa gra } \\
\text { przygodowa 2017 }\end{array}$ \\
\hline
\end{tabular}


Każdy z programów przygodowych opierał się na wyżej wymienionych zasadach metody przygodowej. W programach tych zastosowane zostało badanie w działaniu, na które składała się analiza każdej z grup pod kątem potrzeb, problemów i możliwości działania, obserwacja uczestnicząca (codzienny dziennik obserwacji), analiza wytworów (materiały powstałe w trakcie warsztatów, analiza nagrań wideo), ewaluacja programów (również materiały powstałe w wyniku gier i zadań ewaluacyjnych).

Materiał badawczy jest bardzo obszerny i pozwala na szeroką analizę efektów, jakie przynosi stosowanie programów przygodowych, między innymi pod kątem poszerzania strefy komfortu, budowania zaufania, procesów grupowych, które tutaj zostaną tylko zaznaczone. Pytanie brzmi - czy w wyniku udziału w programach przygodowych uczestnicy podnieśli poziom umiejętności współpracy oraz czy uczestnictwo w programach przygodowych powoduje budowanie wspólnoty.

Trzy z wymienionych programów były realizowane w grupach harcerskich, również w dwóch programach studenckich znaczną część stanowili instruktorzy harcerscy. Harcerski bieg przygodowy był alternatywą do tradycyjnego biegu harcerskiego. Odbywał się w losowych zespołach, które nie pokrywały się z podziałem na zastępy - co miało swoje uzasadnienie w zaobserwowanych problemach. Zadania te były nastawione na współpracę w zespole i między zespołami. Na punktach instruktor obserwował grupę pod kątem umiejętności współpracy, rozwiązywania problemów i przyjmowanych ról, a na koniec poddawał refleksji. Analogicznie została zorganizowana Zuchowa gra przygodowa (zadania były zorganizowane jak obwód stacyjny).

Kurs funkcyjnych obejmował cykl trzygodzinnych, trwających przez pięć dni warsztatów zaplanowanych zgodnie z zasadami dobrej zbiórki oraz metodą przygodową. Uczestnicy realizowali zadania mające charakter wyzwań oraz brali udział w grach nastawionych na współpracę.

Cztery programy realizowane były podczas obozów tanecznych. Celem każdego z nich dla tancerzy było opracowanie na zakończenie spektaklu tanecznego, z określoną myślą przewodnią, składającego się z około dziesięciu układów. Uczestnicy byli zaangażowani w przygotowanie koncepcji spektaklu, tworzenie choreografii, przegotowanie strojów i scenografii. Pracowali zespołowo, nacisk był położony na współpracę, wspólne osiągnięcie celu. Zajęcia taneczne i akrobatyczne w większości odbywały się w plenerze, również końcowy występ był plenerowy. W trakcie poza treningami tanecznymi czy gimnastycznymi uczestnicy mieli też zajęcia, których celem było budowanie zaufania, umiejętności rozwiązywania problemów, czy też stawiane były przed nimi wyzwania pozataneczne. 
Pięć programów realizowanych było wśród studentów. Dwa z nich łączyły w sobie metodę pedagogiki przygody z wykorzystaniem tańca jako środka przygodowego, obejmując 60 godzin rozłożonych na dwa semestry. Pierwszy poświęcony był „oswajaniu się” z zaplanowanym wyzwaniem (zrealizować projekt, który będzie opierał się na wykorzystaniu ruchu i tańca przy zaangażowaniu całej grupy) poprzez nabywanie warsztatu tanecznego oraz udział w grach przygodowych dostosowanych do warunków tanecznych. W drugim semestrze studenci przystępowali do realizacji zaplanowanego przez siebie projektu. Rolą prowadzącego zajęcia było wspieranie grupy oraz obserwacja procesów grupowych. Studenci sami musieli rozwiązywać konflikty w grupie, radzić sobie z niepowodzeniami i elastycznie reagować w zależności od zmieniającej się sytuacji. W efekcie tego programów powstał lip-dub² z zaangażowaniem osób z zewnątrz oraz w ramach projektu PORUSZONE ${ }^{3}$ - dwa filmy taneczne o emocjach - Złość i Radość.

Trzy kolejne programy przygodowe realizowane wśród studentów miały na celu zapoznanie z metodą przygodową. Studenci brali udział w blokach gier o określonym celu (integracja, budowanie zaufania, wzmacnianie uważności, praca w zespole i komunikacja, procesy grupowe, refleksja), a następnie w mniejszych zespołach samodzielnie przygotowali godzinne warsztaty dla swojej grupy, które miały odpowiadać na jej aktualne problemy lub potrzeby.

\section{1. „METRY UMIEJĘTNOŚCI” - CZEGO SIĘ NAUCZYŁEM?}

W czterech programach przygodowych zastosowane zostało to samo narzędzie ewaluacyjne - tzw. metry umiejętności ${ }^{4}$. W analizie udzielanych odpowiedzi ważne jest to, na czym uczestnicy koncentrują się w pierwszej kolejności - czy wypowiedzi się powtarzają? Jakich aspektów dotyczą? Czy można je pogrupować w kategorie?

${ }^{2}$ LipDub Animacja Społeczno-Kulturalna UW, źródło: https://www.youtube.com/watch?v=w2vnqeniII0.

3 Projekt PORUSZONE, źródło: https://www.facebook.com/pg/poruszoneaniamcja/posts/.

4 Autorska metoda podsumowania warsztatów o charakterze animacyjnym mająca na celu otrzymanie informacji zwrotnej. Uczestnicy wypisują na małych kartkach wszystkie umiejętności, które - według własnej oceny - nabyli podczas warsztatów (nie dostają wytycznych, czego mają dotyczyć odpowiedzi, mogą brać pod uwagę całość spędzonego czasu na warsztatach). Następnie wszystkie kartki przyczepiane są na jeden sznurek, a grupa musi dokonać pomiaru tego sznurka bez wykorzystania linijki, miarki czy centymetra. 
W pedagogice przygody ważne są takie zagadnienia, jak: procesy grupowe, podejmowanie współpracy, budowanie zaufania, poszerzanie swojej strefy komfortu - i pod tym kątem były analizowane odpowiedzi.

$\mathrm{Z}$ analizy materiału wynika, że we wszystkich grupach pojawiały się odpowiedzi, które można przyporządkować do trzech kategorii: warsztat pracy, poszerzanie strefy komfortu oraz procesy grupowe. Najczęściej występującą kategorią był warsztat pracy. W jej ramach znalazły się odpowiedzi dotyczące głównego celu warsztatów dla uczestników - w przypadku studentów dotyczyło to poszerzenia swojego zasobu gier, wykorzystania rekwizytów; w grupie tanecznej kategoria ta związana była z nauką nowych choreografii lub poszczególnych elementów taneczno-gimnastycznych; natomiast w grupie kursantów - obejmowały odpowiedzi dotyczące zapoznania się z elementami metody harcerskiej czy zasadami dobrej zbiórki.

W trzech grupach (studenci zaoczni, tancerze, kursanci) ta kategoria zdecydowanie obejmuje ponad połowę wszystkich odpowiedzi - co może wynikać z bardziej praktycznego nastawienia do zajęć uczestników. Studenci studiów zaocznych byli ukierunkowani bardziej na zdobywanie umiejętności praktycznych, takich, które mogli od razu wykorzystać w swojej pracy; dla tancerzy głównym celem obozu było opracowanie nowych choreografii oraz poprawienie swojego warsztatu tanecznego; natomiast dla uczestników kursu funkcyjnych celem przede wszystkim było zdobycie określonych umiejętności z zakresu planowania pracy drużyny, zrozumienia metody harcerskiej. Z tego schematu wyłamują się studenci PP 2018 - jest to grupa bardzo specyficzna, refleksyjna, w której skład wchodzą nie tylko przyszli animatorzy - osoby o określonych pasjach i zainteresowaniach z zacięciem prospołecznym, ale także instruktorzy harcerscy (stanowili połowę grupy). Stąd być może mniejszy nacisk na warsztat pracy.

Kolejną kategorią wyłonioną z odpowiedzi są tzw. procesy grupowe, które stanowią od 1/5 do ponad 1/3 wszystkich odpowiedzi. Tu znalazły się odpowiedzi dotyczące przewodzenia grupie, integracji grupy, a także współpracy.

Natomiast w kategorii poszerzanie strefy komfortu zgrupowane zostały wypowiedzi dotyczące odwagi, przełamywania swoich oporów, samoświadomości mocnych i słabych stron. Kategoria ta w najmniejszym stopniu ujawniła się w grupie studentów zaocznych, a najmocniej wśród studentów dziennych.

Z powyższych ogólnych danych (tabela 2) wynika, że programy przygodowe, przynajmniej częściowo, spełniają swoją rolę - nawet wówczas, kiedy ich główne założenia są niejako ukryte pod widocznymi (dla uczestników) celami działań realizują podstawowe założenia pedagogiki przygody - poszerzają strefę komfortu oraz wpływają na procesy grupowe. 
Tabela 2. Odsetek odpowiedzi w poszczególnych kategoriach (opracowanie własne)

\begin{tabular}{lccccc}
\hline & $\begin{array}{l}\text { Warsztat } \\
\text { pracy }\end{array}$ & $\begin{array}{l}\text { Procesy } \\
\text { grupowe }\end{array}$ & $\begin{array}{l}\text { Poszerzanie } \\
\text { strefy komfortu }\end{array}$ & Inne & $\begin{array}{l}\text { Lączna liczba } \\
\text { odpowiedzi (kartek) }\end{array}$ \\
\hline PP 2018 & $37,1 \%$ & $30,5 \%$ & $\mathbf{3 1 , 4 \%}$ & $1 \%$ & 71 \\
\hline PP 2018N & $56 \%$ & $\mathbf{3 7 \%}$ & $7 \%$ & - & 30 \\
\hline $\begin{array}{l}\text { Obóz } \\
\text { taneczny 2018 }\end{array}$ & $\mathbf{6 0 , 3 \%}$ & $20,7 \%$ & $19 \%$ & - & 63 \\
\hline $\begin{array}{l}\text { Kurs } \\
\text { funkcyjnych }\end{array}$ & $57,4 \%$ & $20,4 \%$ & $22,2 \%$ & - & 54 \\
\hline
\end{tabular}

W pedagogice przygody nacisk położony jest na procesy grupowe, współpracę, stawianie sobie wyzwań - w efekcie czego powinno dojść do zwiększenia samoświadomości swoich możliwości i ograniczeń. Analizując pod tym kątem uzyskane dane można stwierdzić, że wszystkie te aspekty pojawiły się w wypowiedziach uczestników programów przygodowych - aczkolwiek w różnym stopniu były one istotne.

Tabela 3. Odsetek odpowiedzi dotyczących kluczowych umiejętności w pedagogice przygody z podziałem na grupy badanych (opracowanie własne)

\begin{tabular}{lcccc}
\hline & Wspólnota & Wyzwanie & Współpraca & Samoświadomość \\
\hline PP 2018 & $26,8 \%$ & $15,5 \%$ & $16,9 \%$ & $\mathbf{3 9 , 4 \%}$ \\
\hline PP 2018 N & $\mathbf{2 7 \%}$ & $3 \%$ & $13 \%$ & $17 \%$ \\
\hline Obóz taneczny & $7,9 \%$ & $\mathbf{1 9 , 0 \%}$ & $7,9 \%$ & $4,8 \%$ \\
\hline Kurs funkcyjnych & $7,4 \%$ & $5,6 \%$ & $14,8 \%$ & $\mathbf{2 7 , 8 \%}$ \\
\hline
\end{tabular}

Budowanie wspólnoty najliczniej jest podkreślane wśród studentów, co przejawiało się w odpowiedziach:

- Można mieć kryzys i płakać przed grupq;

- Spojrzałam na osoby w grupie w nowy sposób dzięki wspólnie przeżytej przygodzie;

- Zobaczyłam, jak bardzo zgranq jesteśmy grupq;

- Bardziej kocham moja grupę.

Z kolei pod względem stawiania sobie wyzwań, przełamywania swoich barier, poszerzania strefy komfortu wybija się grupa taneczna (19\% wypowiedzi) - co ciekawe wyzwania nie dotyczyły tylko sfery tanecznej, ale także innych towarzyszących zadań:

- Nauczyłam się żyć bez laptopa i telefonu;

- Nauczyłam się kierować kajakiem; 
Drugą w kolejności grupą podkreślającą istotę wyzwań, z jakimi się spotkali, byli studenci:

- Nie poddaję się - jest cel, dqqżę do niego;

- Każdy ma swoje granice;

- Zrobienie czegoś jest prostsze, niż się wydaje, myślenie o tym jest najbardziej przerażające.

Pod względem współpracy wyniki w trzech grupach wyglądają podobnie kilkanaście procent pojawiających się odpowiedzi zwraca uwagę na istotę współdziałania z innymi, a najniższy odsetek jest wśród tancerzy:

- Nauczyłam się pracować w grupach, a zawsze wolałam samodzielnie;

- Nauczyłam się tego, że trzeba być zgranq grupq i współpracować z innymi;

- Bawienia się z innymi.

Ostatnia kategoria dotyczyła samoświadomości - swoich mocnych i słabych stron. Zdecydowanie największy poziom jest wśród studentów, co może wynikać z charakteru studiów i dużej refleksyjności tej grupy. Wysoki odsetek jest również wśród kursu funkcyjnych. Odpowiedzi, jakie tu się pojawiały, to np.:

- Dowiedziałam się, w czym chciałabym się sprawdzić w harcerstwie;

- W czym jestem dobra;

- Poznałam swoje wady i zalety;

- Że lubię doświadczać nowych rzeczy;

- O sobie dowiedziałam się, że powinnam trenować dawanie instrukcji innym, bo czasem sq trochę mało składne;

- Że jak chcę, to potrafię;

- Chcę robić różne dziwne rzeczy;

- Lubię ciszę;

- Lepiej poznałam siebie, swoje możliwości i granice.

Powyższe podkategorie wynikają z założeń pedagogiki przygody i choć same wartości liczbowe nie wyglądają imponująco, to biorąc pod uwagę fakt, że owe cele były tzw. celami ukrytymi - nie były one główne dla uczestników, a jedynie dla prowadzącego - to można uznać to za istotne. Wypowiedzi dotyczące tego, że uczestnicy nabyli umiejętność współpracy, że zadania były dla nich wyzwaniem i dzięki temu dowiedzieli się o sobie czegoś więcej, a także że udało im się zbudować wspólnotę - dowodzą, że sama metoda w pewnej części działa. Warto pamiętać o tym, że takie odpowiedzi mogły nie pojawić się wcale lub mieć negatywny wydźwięk - ponieważ badani nie byli informowani, o czym mają pisać. 


\subsection{CELE GIER}

Kolejną metodą wykorzystywaną w badaniach była analiza przeprowadzonych gier. Uczestnicy programu przygodowego PP 2017 po wzięciu udziału w kilku grach przygodowych mieli na podstawie własnych odczuć określić, co było głównym celem gry - poza oczywistym celem osiągnięcia określonego rezultatu.

Tabela 4. Ukryte cele gier przygodowych wskazywane przez uczestników (opracowanie własne)

\begin{tabular}{|c|c|c|c|c|c|c|}
\hline Cel gry & $\begin{array}{l}\text { Droga } \\
\text { ślepców }\end{array}$ & Wahadło & Wodociąg & Fotografia & $\begin{array}{l}\text { Serce } \\
\text { dzwonu }\end{array}$ & $\begin{array}{l}\text { Poszukiwa- } \\
\text { cze lin }\end{array}$ \\
\hline Komunikacja & 12 & & 1 & 3 & & 12 \\
\hline Zaufanie & 2 & 13 & 1 & 7 & 15 & \\
\hline Współpraca & & & 10 & 1 & & 3 \\
\hline Zorganizowanie & & & 1 & 0 & & \\
\hline Integracja & & & 1 & 3 & & \\
\hline
\end{tabular}

Najczęściej pojawiała się kategoria zaufania, przy czym wyniki są najwyższe przy dwóch zadaniach, gdzie faktycznie bez przełamania swoich oporów i zaufania innym - nie można ich wykonać. Drugim celem, który był najczęściej wymieniany, jest komunikacja. Pojawiała się również istotna z punktu widzenia pedagogiki przygody kategoria - współpraca. Warto zauważyć, że nie były wymieniane kategorie, które okazałyby się sprzeczne z założeniami pedagogiki przygody - np. rywalizacja.

\subsection{WSPÓŁPRACA I SAMODYSCYPLINA}

Istotną kwestią w pedagogice przygody jest również poszerzanie swojej strefy komfortu - czyli „przesuwanie” czynności wywołujących obawy do kręgu umiejętności, które nie sprawiają problemu. Wśród uczestników obozów tanecznych wykonywane jest badanie tzw. kręgów uczenia się. . Analiza obu wypełnionych kart pozwala na spojrzenie, po pierwsze - jakie czynności/umiejętności przychodzą uczestnikom w pierwszej kolejności do głowy, o czym myślą przede wszystkim, a po drugie - czy czynności/umiejętności na koniec obozu ponownie się pojawiły i w którym kręgu?

5 Autorska metoda animacyjna badania stref komfortu - uczenia się - paniki. Uczestnicy dwukrotnie (na początku i na końcu) w trzech kręgach wypisują umiejętności/czynności, które odpowiednio: nie sprawiają im żadnego problemu; są dla nich wyzwaniem oraz panicznie się ich boją. Celem jest sprawdzenie, czy na obu kartach pojawiły się te same czynności oraz czy zmieniły one swoje pozycje. 
Przesunięcie się elementów ze strefy paniki w kierunku strefy komfortu mogą świadczyć o poszerzeniu tej ostatniej. Odwrotny kierunek będzie świadczył o jej „kurczeniu się”. Pojawienie się nowych elementów może wynikać z koncentracji na innych aspektach w danym momencie lub uświadomienia sobie nowych czynności/umiejętności, z którymi wcześniej nie mieli kontaktu.

Analizując otrzymane dane, można wywnioskować, że zmiany występują u mniej niż połowy uczestników. O tym, że nastąpiła pozytywna zmiana, mogą świadczyć wpisy w strefach po obozie:

- Co jest dla Ciebie wyzwaniem?

- Już nic.

- Czego panicznie się boisz?

- Niczego;

- Niczego, ze wszystkim jakoś sobie mogę poradzić.

W drugim badaniu uczestnicy wypełniają również pola koła (określane przez nich samych „pizzą”) ${ }^{6}$.

Ciekawe są odpowiedzi w części Nauczyłem/am się... świadczące o osiąganiu ukrytych pożądanych celów:

- wzroście samodyscypliny:

- Że nie odpuściłem sobie $w$ trakcie treningów albo przed występem;

- Żyć bez światła;

- Utrzymywać ład;

- Wstawać o 7:00;

- Radzić sobie w trudnych warunkach;

- Systematyczności;

- Wytrzymałości;

- Żyć z pająkami i innymi robaczkami w jednym domku.

- nabywaniu wiary we własne możliwości:

- Że z każdej sytuacji jest jakieś wyjście, nie ma rzeczy niemożliwych.

A także - co istotne z punktu podjętego tematu - uczeniu się współpracy:

- pracy w zespole;

- nauczyłam się, że trzeba pomagać i akceptować innych;

- współpracować z innymi;

- wymyślanie układu w grupie.

${ }^{6}$ W drugim badaniu „Kręgi uczenia się” uczestnicy uzupełniają także odpowiedziami pole koła podzielone na osiem części, kończąc zdania: nauczyłam się..., zaskoczyło mnie..., zdenerwowało mnie.... To zadanie przez uczestników zostało określone „pizzą” - stąd też nazwa. 
Podobna liczba wypowiedzi dotyczy również nabywania umiejętności związanych bezpośrednio z tańcem i gimnastyką - co świadczy o tym, że koncentracja nie była tylko na tanecznym celu obozu.

Warto wspomnieć również o odpowiedzi wskazujące na kształtowanie charakteru, np.: cierpliwość, dystans do siebie, pewność siebie, nawiq̨zywanie kontaktów z ludźmi.

Co ciekawe, tak pozytywnych wyników dotyczących budowania współpracy, umiejętności rozwiązywania konfliktów w grupie nie osiągnięto w dwóch innych programach, które różniły się dwoma aspektami - grupą odbiorców były osoby dorosłe, program zorganizowany był w formie cyklicznych cotygodniowych spotkań. Sam projekt był dla obu grup dużym wyzwaniem i obie przeszły całą ścieżkę rozwoju grupy (od zapoznania, przez konflikt, sukces, aż do rozwiązania grupy), a także zdobyły wiele istotnych i wartościowych doświadczeń, co podkreślały w podsumowaniu - to akurat w zakresie współpracy i przyjmowanych ról w zespole niewiele to zmieniło. Z badań „Kręgów uczenia się” natomiast wynikało, że zaszła pozytywna zmiana. Oba projekty miały formę stacjonarną - cyklicznych cotygodniowych spotkań. Grupa spotykała się, żeby zrealizować zadanie i rozchodziła do swoich, codziennych obowiązków. Powodowało to mniejszą intensywność odczuwania wyzwania, a także stwarzało możliwość pracy samodzielnej/zdalnej nad projektem.

Na podstawie tych wyników można się pokusić o hipotezę dotyczącą długości i sposobu organizacji programu przygodowego. Najlepsze rezultaty daje projekt kilkudniowy, w trakcie którego grupa jest niejako odizolowana od swojego codziennego środowiska, lepsze rezultaty uzyskuje się także wówczas, kiedy pojedyncze spotkanie trwa dłużej niż tylko typowe półtorej godziny. Projekt nadmiernie rozciągnięty w czasie daje najmniejsze rezultaty pod względem zmian w sposobie pracy.

Potwierdzeniem tej hipotezy są również wyniki uzyskane w innym programie przygodowym wśród harcerzy. Realizacja jednorazowych krótkich programów przygodowych - kilkugodzinnych - pokazała, że nie można mówić o trwałej zmianie postaw czy też nabyciu kompetencji społecznych. Można to potraktować jako wstęp, pierwszy krok w kierunku refleksji nad działaniami.

Jak wynika z powyższego, nie wszystkie programy przygodowe przynoszą zamierzone efekty we wszystkich obszarach. Zazwyczaj dość dobrze osiągane są cele bezpośrednio stawiane sobie przez uczestników (przygotowanie lip-dub, choreografii, projektu), ale nie jest to jednoznaczne z rozwijaniem się w strefach skazanych przez pedagogikę przygody. 


\subsection{TRUDNA RYWALIZACJA}

Obserwacja harcerzy podczas biegu przygodowego pokazała, że bardzo trudno było im pozbyć się wyuczonych odruchów rywalizacyjnych, o czym świadczą zachowania na poszczególnych punktach: wzajemnie poganianie siebie, dopytywanie się, w jakim czasie wykonali zadanie i czy byli lepsi od innych, a także frustracja, z którą trudno było im sobie poradzić, jeśli zadanie nie zakończyło się sukcesem.

Co ciekawe, dużo lepiej z przyjmowaniem nowych zasad radzili sobie młodsi uczestnicy gier przygodowych - zuchy. Wykonując zadania sami się upominali, że to przecież nie jest na czas; nie ścigamy się; musimy to zrobić razem. Zaskoczenie - ale tylko chwilowe, wzbudziło w zuchach podsumowanie „Niech na środek wyjdzie ten, kto jest... (wypoczęty/ znudzony/ zadowolony/ zły/ zmęczony)”. Jeden z punktów Prawa Harcerskiego mówi, że harcerz ma być zawsze pogodny, radosny i uśmiechnięty, co często w konsekwencji prowadzi do skrajnego interpretowania tego zapisu - że nie można odczuwać negatywnych emocji. W związku z tym często nie mówią o tych emocjach otwarcie, harcerze nie przyznają się do takich odczuć ${ }^{7}$. W pedagogice przygody uświadomienie negatywnych emocji jest konieczne do pełnej samoświadomości. Przeżywanie negatywnych emocji w sytuacji gry pozwala uczestnikom zrozumieć, jak reagują w różnych sytuacjach.

Podczas refleksji zwracana była uwaga na to, żeby inni uczestnicy nie oceniali ani wyborów, ani odpowiedzi swoich kolegów i koleżanek - co zuchy zaakceptowały dość szybko - i znowu, jak przy grach - same się upominały o swoje prawa - ale ja mam prawo tak uważać, ale ja właśnie tak to czuję.

\subsection{WIEK A PRZYSWAJANIE NOWYCH ZASAD}

Powyższa obserwacja ma również odzwierciedlenie w zachowaniach dorosłych. Największe trudności z przyswojeniem i zaakceptowaniem zasad wynikających z organizacji programów przygodowych, przebiegu gier i roli prowadzącego miała... kadra, czyli najstarsi instruktorzy. Przede wszystkim zwracali oni uwagę na to, że bardzo trudno było im nie angażować się w wykonywanie zadania, stać z boku i tylko obserwować:

- Musiałem się ciagle gryźć w język, żeby im nie podpowiadać;

- Byłam zdziwiona tym, że mogę mówić, co mi się nie podobało;

- Z rozpędu mierzyłam każdej grupie czas wykonania zadania;

7 Por. wyniki badań opublikowane: Palamer-Kabacińska, 2014. 
- Trudno jest nie oceniać tego, co mówiq na podsumowaniu, zwłaszcza jeśli sq to negatywne wypowiedzi.

Podobne obserwacje można poczynić w innych programach przygodowych, w których uczestnikami byli instruktorzy.

Na podstawie powyższych wyników można wysnuć wnioski - które wynikają z ogólnych prawideł psychologii i socjologii:

- młodsi łatwiej przyswajają nowe zasady i reguły gry;

- im krótszy program przygodowy, tym mniej trwałe zmiany postaw.

Młodszy wiek sprzyja efektywności uczenia się nowych rzeczy, a także długość kontaktu z określonym czynnikiem społecznym koreluje z trwałością nabywanych nawyków, na co zwracali uwagę już wcześniej klasycy pedagogiki społecznej: Helena Radlińska (1968) uważała, że aby doszło do zmiany wśród uczestników danego środowiska wychowawczego, muszą oni mieć długotrwały kontakt z bodźcem, z kolei Ryszard Wroczyński (1974) zwracał uwagę na intensywność tego bodźca. Oba postulaty w przypadku programów przygodowych mają znaczenie.

Podsumowując, warto podkreślić, że programy przygodowe, choć rzadko analizowane w polskiej literaturze, mogą stać się ważnym elementem kształcenia umiejętności wymaganych na współczesnym rynku - uczą rozwiązywania problemów, współpracy, budują zaufanie. I choć nie zawsze osiąga się spektakularne wyniki, to warto je wprowadzać w ramach edukacji, nie tylko pozaformalnej.

\section{Bibliografia}

Leśny, A. (2014). Pedagogika przygody - konteksty teoretyczne. W: A. Bąk, A. Leśny, E. Palamer-Kabacińska (red.), Przygoda w edukacji i edukacja w przygodzie. Outdoor $i$ adventure w Polsce (s. 12-49). Warszawa: FPNiP.

Outward Bound (b.d.). Pobrane z: outwardbound.org.

Palamer-Kabacińska, E. (2012). Miejsce pedagogiki przygody w naukach pedagogicznych. W: A. Leśny, E. Palamer-Kabacińska (red.), Edukacja przygodq. Outdoor i adventure education w Polsce: teoria, przykłady, konteksty (s. 12-33). Warszawa: FPNiP.

Palamer-Kabacińska, E. (2014). Pełnić służbę całym życiem. Ruch harcerski jako przykład organizacji pozarzq̨dowych wdrażajq̨cych do społeczeństwa obywatelskiego. Kraków: Impuls.

Prázdninová škola Lipnice (b.d.). Pobrane z: https://www.psl.cz/.

Radlińska, H. (1961). Pedagogika społeczna. Wrocław: Zakład Narodowy im. Ossolińskich. Raport GUMTREE, Aktywni+-- przyszłość rynku pracy. (2017). De Lab UW. Pobrane z: http://www.delab.uw.edu.pl/wp-content/uploads/2017/04/DELabUW_raport_Aktywni.pdf.

Ryszka, R. (2016). Pedagogika przeżyć. Praktycznie. Kraków: Impuls.

Szmagalski, J. (1988). Przewodzenie małym grupom. Działanie grupowe. Warszawa: CAK. 
Uczyć się inaczej. Kompendium wiedzy o edukacji pozaformalnej na podstawie doświadczeń uczestników i uczestniczek Programu „Młodzież w działaniu” (2007-2013). (2014). Warszawa: FRSE.

Wroczyński, R. (1974). Pedagogika społeczna. Warszawa: PWN.

Zalecenie Rady z dnia 22 maja 2018 r. w sprawie kompetencji kluczowych w procesie uczenia się przez całe życie. Pobrane z: https://eur-lex.europa.eu/legal-content/PL/ TXT/PDF/?uri=CELEX:32018H0604(01)\&from=EN. 